Nama : Ummu Kaltsum. M

Nim : 90100118023

Kelas : Ekonomi Islam A

\title{
SEJARAH PEMIKIRAN EKONOMI ISLAM
}

Di sejarah pemikiran ekonomi islam terdapat beberapa fase, fase pertama pada masa nabi muhammad saw. : Bebagai penerapan dan kebijakan ekonomi yang dilakukang pada masa nabi muhammad saw dan al khulafa al - rasyidun merupan salah satu contoh empiris yang dijadikan patokan bagi para cendekiawan muslim dalam melahirkan teori - teori ekonominya. Suatu hal yang jelas, fokus perhatian mereka terttuju pada pemenuhan kebutuhan, keadilan, efisisensi, pertumbuhan, dan kebebasan yang tidak lain merupakan objek utama yang memotivasi pemikiran ekonmi islam. ${ }^{1}$ Sumber - sumber islam berasal dari al-qur'an dan Sunnah, yang berisi sejumlah prinsip - prinsip ekonomi dan beberapa ajaran ekonomi secara rinci. Oleh karena itu kita tidak perlu mencari sumber - sumber asing. Pemikiran ekonomi islam pada dasarnya diawali pada sumber - sumber internal tersebut. Ajaran Al - Qur'an tentang masalah ekonomi bersifat spesifik dan sedikit jumlahnya. Al Qur'an menyampaikan sebagian besar prinsip - prinsip tersebut dan mementingkan pada penggunaan pikiran dan penggunaan penalaran. Hal ini disebabkan munculnya sanad para ulama yang berisi aturan untuk mentuntaskan masalah baru dan menciptakan logika hukum ( ushul al fiqh ) yang berlaku untuk berbagai pola sosial. Metodologi pertama mereka adalah merujuk pada al - qur'an dan praktik nabi muhammad

Kehipuan nabi muhammad saw dan masyarakat muslim di masa beliau adalah pedoman yang paling baik pelaksanaan islam, termasuk dalam bidang ekonomi. Pada masa di Makkah masyarakat muslim belum sempat membangun perekonomian, sebab pada masa itu penuh dengan perjuangan untuk mempertahankan diri dari bahaya orang - orang quraisy. Pada saat itulah pada masa madinah rasulullah mempimpin sendiri untuk membangun masyarakat madinah sehingga membuat masyarakat menjadi sejahtera dan beradab.

\footnotetext{
${ }^{1}$ Jaelani, A. (2018). Sejarah Pemikiran Ekonomi Islam: Kontribusi Sarjana Muslim dalam Pemikiran dan Analisis Ekonomi.
} 
Walaupun perekonomian pada masa beliau relatif masi simpel, tetapi beliau telah memperlihatkan prinsip - prinsip yang mendasar bagi pengelolaan ekonomi. ${ }^{2}$

Sosial Ekonomi Umat Islam pada Masa al-Gazali ini berlangsung hingga tahun 660 M, dimana formasi perekonomian masih didominasi corak nomadis. Tahap kedua, tahun 660950 disebut dengan era negara-negara agraris pemberi upeti, dimana masyarakat pada umumnya beralih dari corak kehidupan nomaden ke arah agraris. Tahap ketiga, antara tahun 950-1550 disebut dengan era negara-negara perdagangan pemberi upeti karena aktivitas perekonomian pada era tersebut didominasi oleh aktifitas perdagangan. Tahap keempat, tahun 1550-1850 adalah tahap formasi kegiatan kerajaan pinggiran yang bercirikan dengan kecenderungan masyarakat untuk meninggalkan cara-cara hidup dalam koloni kecil dan membentuk koloni yang lebih besar dalam bentuk kerajaan. Dan tahap kelima, antara tahun 1850 hingga sekarang disebut dengan istilah era kapitalisme pinggiran. ${ }^{3}$

Pemikiran Ekonomi Islam pada Masa Kontemporer Muhammad Abdul Mannan Beberapa asumsi dasar dalam ekonomi Islam, Mannan tidak percaya kepada "harmony of interests" yang terbentuk oleh mekanisme pasar seperti teori Adam Smith. Sejatinya harmony of interests hanyalah angan-angan yang utopis karena pada dasarnya setiap manusia mempunyai naluri untuk menguasai pada yang lain. yed Nawab Haedir Naqvi Menurut Syed Nawad Haidir Naqvi, ekonomi Islam berakar pada pandangan dunia khas Islam dan premispremis nilainya diambil dari ajaran- ajaran etik-sosial al-Qur'an dan Sunnah. Ekonomi Islam berpijak pada landasan hukum yang pasti yang mempunyai manfaat untuk mengatur masalah kemasyarakatan, sehingga hukum harus mampu menjawab segenap masalah manusia, baik masalah yang besar sampai sesuatu masalah yang belum dianggap masalah. Monzer al kahf termasuk orang pertama yang mengaktualisasikan analisis penggunaan beberapa institusi Islam (seperti zakat) terhadap agregat ekonomi, seperti simpanan, investasi, konsumsi dan pandapatan.

\footnotetext{
${ }^{2}$ Fauzan, I. (2019). THE THE THINGKING OF ISLAMIC ECONOMY IN MUHAMMAD PROPHET ERA (PEMIKIRAN EKONOMI ISLAM PADA MASA NABI MUHAMMAD). Risâlah, Jurnal Pendidikan dan Studi Islam, Vol 5 No 1, hal 51-61.

${ }^{3}$ Sirajuddin, S. (2016). Konsep Pemikiran Ekonomi Al-Ghazali. Laa Maisyir: Jurnal Ekonomi Islam, Vol 3 No 1.
} 